\title{
Pengaruh Kompetensi Dosen terhadap Prestasi Akademik Mahasiswa Fakultas Ekonomi dan Bisnis Telkom University
}

\section{Influence of Lecturers' Competence to Student's Academic Achievement of Faculty Economics nnd Business Telkom University}

\author{
Ridyantoro Widoyo Murti ${ }^{1}$, Arif Partono Prasetio ${ }^{2}$ \\ Universitas Telkom, Bandung, Indonesia \\ ridyantorowidoyomurti@yahoo.com ${ }^{1}$,partono67@gmail.com² \\ Naskah diterima tanggal 9/6/2018, Direvisi akhir tanggal 15/7/2018, disetujui tanggal 15/8/2018
}

\begin{abstract}
Abstrak
Sumber daya manusia merupakan sumber yang berperan penting dalam rangka mencapai tujuan suatu institusi. Pengelolaan sumber daya manusia yang baik akan berdampak positif bagi institusi yang bersangkutan. Penelitian ini bertujuan untuk mengukur pengaruh tingkat kompetensi dosen terhadap prestasi akademik mahasiswa tahun angkatan 2014, 2015, dan 2016 di Fakultas Ekonomi dan Bisnis Telkom University. Penelitian dilakukan di Kabupaten Bandung, Jawa Barat, Indonesia dengan menggunakan 343 responden mahasiswa. Seperti diketahui bahwa salah satu tujuan proses belajar mengajar adalah adanya peningkatan pemahaman mahasiswa yang pada akhirnya akan terefleksi pada prestasi mereka. Salah satu faktor penting untuk meningkatkan prestasi mahasiswa adalah kompetensi pendidik. Pendidik yang kurang memiliki kompetensi di bidangnya dapat mengganggu pencapaian sasaran tersebut. Pengumpulan data dilakukan dengan kuesioner yang berisi 28 pernyataan. Data penelitian ini memenuhi Uji Asumsi Klasik yang berarti bisa digunakan untuk menganalisis pengaruh variabel independen dengan menggunakan Analisis Regresi Linier Sederhana. Temuan menunjukkan bahwa kompetensi dosen tidak memiliki hubungan yang signifikan dengan prestasi akademik mahasiswa, dengan nilai R2 sebesar 0,001 dan nilai Sig. 0,570.
\end{abstract}

Kata Kunci: kompetensi dosen, prestasi akademik, perguruan tinggi

\begin{abstract}
Human resources is a source that plays important role in order to achieve the objective of an institution. A good human resource management will have positive impact toward related institution. This research is aimed to measure the level of lecturers' competence toward student's academic achievement in the year of classes 2014, 2015, and 2016 of Faculty of Economics and Business of Telkom University. Research was held in the district of Bandung, West Java, Indonesia with 343 respondents of student. As we know that one of learning process objectives is to enchance student's comprehension that will be reflected on their academic achievement. One of the important thing to enhance student's academic achievement is the lecturers' competence. Lecturer that has lackness on competence in their field could interfere the objectives of achievement. Data collection was conducted with questionaire that contained 28 statement. This data collection fulfilled Classic Assumption Test which could be used to analyze the influence of independent variable with Simple Linear Regression Analysis. Research findings showed that lecturers' competence does not have significant relationship toward student's academic achievement, with $R \neg \neg 2$ value of 0,001 and Sig. value of 0,570.
\end{abstract}

Keywords: lecturers' competence, academic achievement, higher education 


\section{PENDAHULUAN}

Kualitas suatu institusi pendidikan dapat dilihat dari kualitas lulusan yang dihasilkannya. Prestasi mahasiswa sebagai lulusan dari perguruan tinggi nantinya akan dinilai penting sebagai bekal untuk terjun ke dunia kerja karena kebutuhan perusahaan yang semakin dinamis dengan menuntut lulusan perguruan tinggi untuk memiliki tingkat pendidikan yang unggul (Mushtaq, Khan, Shabana, \& Khan, 2012). Oleh karena itu, semakin tinggi prestasi mahasiswa, maka semakin tinggi kualitas lulusan dan secara tidak langsung menaikan tingkat pendidikan di suatu negara.

Mediawati (2010) menyatakan bahwa prestasi akademik adalah kecakapan nyata atau actual ability, yaitu kecakapan yang segera dapat didemonstrasikan dan diuji sekarang juga karena merupakan hasil usaha atau belajar yang bersangkutan dengan teknik tertentu yang telah dijalaninya. Prestasi belajar adalah penguasaan pengetahuan atau keterampilan yang dikembangkan oleh mata pelajaran yang lazimnya ditunjukkan dengan nilai tes atau angka nilai yang diberikan oleh guru (Simamora, 2014).

Terdapat berbagai pendekatan untuk mengukur prestasi mahasiswa. Beberapa peneliti menggunakan nilai per semester atau per tingkat, dan ada pula yang menggunakan indeks prestasi kumulatif (IPK) (Astuty, 2015). Muzenda (2013) mengutarakan bahwa penilaian prestasi akademik mahasiswa dapat menggunakan pendekatan rata-rata nilai keseluruhan dari semua mata kuliah yang diambil oleh mahasiswa per semester tahun kalender akademik atau dapat disebut dengan Indeks Prestasi Kumulatif (IPK).
Terdapat faktor internal dan eksternal yang mempengaruhi pencapaian prestasi akademik mahasiswa secara optimal. Faktor internal tersebut adalah kondisi jasmani dan rohani mahasiswa, sedangkan faktor eksternal berupa kondisi lingkungan di sekitar mahasiswa (Mustofa, 2015). Senada dengan pendapat Rahmawati, Siswandari, \& Ivada (2013), yang mengemukakan bahwa faktor internal yang dapat mempengaruhi prestasi belajar mahasiswa adalah faktor jasmaniah, faktor psikologis, dan faktor kelelahan. Kemudian faktor eksternal yang dapat mempengaruhi prestasi belajar adalah faktor keluarga, faktor sekolah, dan faktor masyarakat.

Salah satu faktor eksternal yang penting dalam sistem pendidikan yaitu pengajar, guru, atau dosen. Ganyaupfu (2013) menegaskan bahwa faktor kompetensi dosen, metode pengajaran, dan kualitas materi pembelajaran adalah faktor yang dapat mendukung mahasiswa agar mampu meraih prestasi akademik yang baik. Hal ini senada dengan Abbasi \& Mir (2012) yang menyatakan bahwa karakteristik guru yang meliputi kualifikasi guru, pengalaman guru, pelatihan guru, dan gaya mengajar dapat mempengaruhi perolehan nilai siswa.

Kompetensi itu sendiri merupakan seperangkat pengetahuan, keterampilan, dan perilaku yang harus dimiliki, dihayati, dan dikuasai oleh guru atau dosen dalam melaksanakan tugas keprofesionalan. Kompetensi guru mencakup beberapa hal antara lain tingkat pengetahuan, keterampilan, dan perilaku yang dimiliki guru dalam menjalankan tugasnya mendidik, mengajar, membimbing, mengarahkan, 
melatih, menilai, dan mengevaluasi peserta didik (Undang-Undang Republik Indonesia Nomor 14 Tahun 2006 Tentang Guru dan Dosen, 2006).

Kompetensi adalah karakteristik yang mendasari seseorang berkaitan dengan efektivitas kinerja individu dalam pekerjaannya atau karakteristik dasar individu yang memiliki hubungan kausal atau sebagai sebab-akibat dengan kriteria yang dijadikan acuan, efektif atau berkinerja prima atau superior di tempat kerja atau pada situasi tertentu (Moeheriono, 2010). Melalui peran, kompetensi, dan kedudukan dosen, maka mutu lulusan dan kepemilikan skill mahasiswa akan selalu menjadi prioritas bagi perguruan tinggi. Salah satu aspek penting yang dapat mempengaruhi kinerja mahasiswa adalah dosen (Aziz, 2016).

Danim (2008) menjelaskan empat faktor yang dapat digunakan untuk mengukur tingkat kompetensi guru atau dosen. Pertama, kompetensi pedagogik yang meliputi kemampuan guru dalam membuat sistem dan materi pembelajaran. Kedua, kompetensi kepribadian berupa sikap dan tindakan guru selama melakukan proses belajar mengajar. Ketiga, kompetensi sosial yang mencakup kemampuan guru dalam berinteraksi dan berkomunikasi dengan siswa, atasan, teman, dan masyarakat. Keempat, kompetensi profesional yang melihat sejauhmana guru memahami dan menguasai materi pembelajaran.

Urgensi dari pengembangan kompetensi dosen sendiri, menurut Moeheriono (2010) adalah sebagai acuan kesuksesan awal bekerja seseorang, sebagai dasar untuk merekrut karyawan yang baik dan handal, sebagai dasar penilaian dan pengembangan karyawan selanjutnya, serta sebagai dasar penilaian kinerja dan pemeberian kompensasi atau sebagai hukuman. Kompetensi yang dimiliki oleh seorang dosen menjadi faktor penting dalam pencapaian prestasi akademik mahasiswa (Yousef, 2017; Ganyaupfu, 2013; Wagiran, 2013). Dengan kata lain prestasi akademik mahasiswa adalah cerminan dari keberhasilan seorang dosen dalam mengajar.

Beberapa penelitian, telah menganalisis hubungan antara kompetensi guru dan prestasi belajar. Diantaranya adalah penelitian yang dilakukan oleh Muzenda (2013), penelitian ini dilakukan di Afrika Selatan, dengan hasil penelitian yang menemukan bahwa pengetahuan subjek, keterampilan mengajar, kehadiran dosen, dan sikap dosen memiliki pengaruh positif yang signifikan terhadap prestasi akademik siswa. Penelitian Akiri \& Ugborugbo (2009) di Nigeria, dengan 300 guru sebagai responden memperlihatkan bahwa guru yang efektif menghasilkan siswa yang berkinerja lebih baik.

Penelitian Astuty (2015) di Bandung, Indonesia menunjukkan hal yang sama bahwa kompetensi dosen (pengajar) berdampak signifikan terhadap prestasi akademik siswa. Hasil serupa didapatkan oleh Wamala \& Seruwagi (2012) yang melakukan penelitian di Uganda. Kompetensi guru yang tinggi mempengaruhi prestasi akademik siswa yang tinggi dalam membaca dan berhitung.

Meski sebagian besar penelitian terdahulu menyatakan adanya hubungan signifikan dan positif antara kompetensi guru dan prestasi siswa, akan tetapi Bonney, Amoah, Micah, \& Lemaire (2015) yang melakukan penelitian di Ghana memperlihatkan hasil 
yang berlawanan. Tingginya kualitas guru dalam hal kualifikasi akademik dan profesional ternyata tidak mempengaruhi hasil belajar siswa. Hasil serupa didapatkan juga oleh Kosgei, Mise, Odera, \& Ayugi (2013), yang melakukan penelitian di Kenya ini menunjukkan tidak ada hubungan yang signifikan antara kualifikasi guru dan prestasi akademik siswa. Begitu pula dengan penelitian yang dilakukan Al-Mutairi (2011) di Kuwait menemukan bahwa tidak ada hubungan signifikan antara kualitas dosen dengan prestasi akademik mahasiswa.

Kontradiksi hasil ini menjadikan penelitian yang mengukur hubungan antara kompetensi guru atau dosen dan prestasi belajar siswa menarik untuk dikaji lebih lanjut. Pada literatur terdahulu terlihat bahwa hasil dari Afrika Selatan, Nigeria, Uganda, dan Indonesia membuktikan bahwa kompetensi guru berpengaruh positif signifikan terhadap prestasi belajar siswa. Sedangkan hasil dari Ghana dan Kenya menunjukkan hal yang sebaliknya. Ini berarti kajian terkait kompetensi guru dan prestasi siswa perlu untuk diteliti kembali dengan menggunakan negara yang berbeda, responden yang berbeda, metode yang berbeda, ataupun dengan alat ukur yang berbeda pula.

Fakultas Ekonomi dan Bisnis Telkom University sangat memperhatikan kualitas lulusannya, itulah alasan mengapa perguruan tinggi ingin membantu mahasiswa untuk meraih minimal standar IPK untuk melamar pekerjaan di berbagai industri. Institusi akan selalu berfokus pada faktor yang dapat mempengaruhi perolehan IPK tersebut. Penelitian ini akan membantu institusi untuk menganalisis apakah kompetensi yang dimiliki dosen di Fakultas Ekonomi dan Bisnis Telkom University dapat membantu meningkatkan pencapaian belajar mahasiswa dalam kaitannya dengan indeks prestasi kumulatif (IPK). Berdasarkan penelitian terdahulu, terkait pengaruh kompetensi dosen terhadap prestasi akademik mahasiswa, peneliti mengajukan hipotesis sebagai berikut:

1. $H_{0}$ : tidak terdapat pengaruh signifikan positif antara kompetensi dosen terhadap prestasi akademik mahasiswa Fakultas Ekonomi dan Bisnis Telkom University tahun angkatan 2014, 2015, dan 2016.

2. $H_{l}$ : terdapat pengaruh signifikan positif antara kompetensi dosen terhadap prestasi akademik mahasiswa Fakultas Ekonomi dan Bisnis Telkom University tahun angkatan 2014, 2015, dan 2016.

\section{METODOLOGI PENELITIAN}

\section{Responden}

Penelitian ini merupakan penelitian kuantitatif yang ditujukan untuk mencari tahu hubungan antara kompetensi dosen terhadap prestasi akademik mahasiswa. Total populasi sebanyak 2.411 mahasiswa Fakultas Ekonomi dan Bisnis Telkom University tahun angkatan 2014, 2015, dan 2016. Untuk metode sampling, peneliti menggunakan metode probability sampling dengan teknik pengambilan proportionate stratified random sampling. Dengan teknik sampling tersebut, peneliti memperoleh 343 mahasiswa sebagai sampel dalam penelitian ini. Data dikumpulkan dengan menyebarkan kuesioner. Pada penelitian ini dikategorikan karakteristik responden terdiri dari 46,1\% laki-laki dan 53,9\% perempuan. Untuk 
kategori tahun angkatan diketahui persentase tertinggi adalah mahasiswa angkatan 2016 dengan persentase sebesar $37,9 \%$, sementara persentase terendah adalah mahasiswa angkatan 2014 dengan persentase sebesar 28,57\%. Kemudian dalam kategori perolehan
IPK persentase tertinggi adalah mahasiswa dengan rentang IPK 3.00-3.49 yaitu sebesar $51,3 \%$, sementara persentase terendah adalah IPK $\leq 1.99$ yaitu sebesar $0 \%$ dari total responden. Untuk lebih jelasnya dapat dilihat melalui tabel 1.

Tabel 1

Aspek demografis

\begin{tabular}{llll}
\hline \multicolumn{1}{c}{$\begin{array}{c}\text { Faktor } \\
\text { Demografis }\end{array}$} & \multicolumn{1}{c}{ Klasifikasi } & \multicolumn{1}{c}{$\begin{array}{c}\text { Jumlah } \\
\text { Responden }\end{array}$} & \multicolumn{1}{c}{ Persentase } \\
\hline \multirow{2}{*}{ Jenis Kelamin } & Laki-laki & 158 & $46,1 \%$ \\
& Perempuan & 185 & $53,9 \%$ \\
Tahun Angkatan & 2014 & 98 & $28,57 \%$ \\
& 2015 & 115 & $33,53 \%$ \\
& 2016 & 130 & $37,9 \%$ \\
IPK & $\leq 1.99$ & 0 & $0 \%$ \\
& $2.00-2.49$ & 4 & $1,2 \%$ \\
& $2.50-2.99$ & 36 & $10,5 \%$ \\
& $3.00-3.49$ & 176 & $51,3 \%$ \\
\hline
\end{tabular}

\section{Teknik Analisis Data}

Metode yang digunakan untuk menganalisis data dalam penelitian adalah analisis regresi linier sederhana dan analisis deskriptif. Regresi bertujuan untuk menguji pengaruh antara variabel satu dengan variabel lainnya, sedangkan regresi linier sederhana adalah regresi yang memiliki satu variabel dependent dan satu variabel independent (Sujarweni, 2016).

Untuk pengolahannya penulis menggunakan bantuan software SPSS versi 21 . Analisis deskriptif merupakan perubahan data dasar, dengan cara menggambarkan karakteristik dasar yang meliputi kecenderungan sentral, distribusi, dan variabilitas (Zikmund, 2010). Jadi tujuan analisis regresi linier sederhana dalam penelitian ini untuk mengetahui pengaruh kompetensi dosen sebagai variabel bebas (independent variable) terhadap prestasi akademik mahasiswa sebagai variabel terikat (dependent variable).

\section{Pengukuran}

Data primer yang dibutuhkan dikumpulkan dengan penyebaran kuesioner yang terdiri dari total 28 item pernyataan; 9 item pernyataan untuk dimensi kompetensi pedagogik, 8 item pernyataan untuk dimensi kompetensi kepribadian, 6 item pernyataan untuk dimensi kompetensi sosial, dan 5 item pernyataan untuk dimensi kompetensi profesional. Item-item tersebut digolongkan ke dalam pernyataan variabel bebas (independent variable). Sedangkan untuk variabel terikat (dependent variable), responden diharuskan memilih rentang perolehan IPK yang sudah disediakan dan menuliskan IPK secara detail. Kuesioner yang disebarkan menggunakan skala 5 poin Likert yang terdiri dari (1) sangat tidak setuju, (2) tidak setuju, (3) netral, (4) setuju, (5) sangat setuju. Dimensi yang digunakan untuk variabel kompetensi terdiri dari kompetensi 
pedagogik, kompetensi kepribadian, kompetensi sosial, kompetensi profesional (Danim, 2008). Contoh pernyataannya yaitu "Dosen melibatkan mahasiswa aktif berpartisipasi dalam pembelajaran". Untuk variabel prestasi akademik pengukurannya menggunakan indeks prestasi kumulatif (IPK) seperti yang digunakan oleh Astuty (2015) dalam penelitiannya.

Seluruh pernyataan sudah diuji dengan uji validitas dan reliabilitas. Berdasarkan hasil hasil uji validitas, terdapat dua pernyataan yang tidak valid karena $r$ hitung lebih kecil dari $\mathrm{r}$ tabel dengan tingkat signifikansi 5\% $(0,05)$. Dua pernyataan yang tidak valid tersebut kemudian tidak digunakan, dan menyisakan dua puluh delapan pernyataan yang semuanya valid dapat digunakan untuk penyebaran kuesioner. Seluruh pernyataan juga dapat dinyatakan reliabel, dengan Cronbach's Alpha untuk kompetensi menunjukkan angka 0,880. Berdasarkan formula Cronbach's Alpha, nilai tersebut memiliki derajat keandalan bagus (good) (Silalahi, 2015).

\section{HASIL DAN PEMBAHASAN}

Hasil uji regresi linier sederhana pada tabel 2 yaitu nilai signifikansi (Sig.) kompetensi dosen sebesar 0,570. Menurut Sujarweni 2016) apabila nilai signifikansi lebih besar dari 0,05 maka $\mathrm{H}_{0}$ diterima, akan tetapi jika nilai signifikansi lebih kecil dari $0,05 \mathrm{H}_{0}$ ditolak dan $\mathrm{H}_{1}$ diterima. Sesuai hipotesis yang telah diajukan oleh penulis sebelumnya, dapat disimpulkan bahwa kompetensi dosen tidak berpengaruh secara signifikan terhadap prestasi akademik mahasiswa Fakultas Ekonomi dan Bisnis Telkom University tahun angkatan 2014, 2015, dan 2016. Pada penelitian ini, penulis menggunakan uji asumsi klasik yang terdiri dari uji normalitas data menggunakan Kolmogorov-Smirnov, uji heteroskedastisitas menggunakan uji Glejser, dan uji koefisien determinasi.

Hasil uji normalitas pada tabel 3 menggunakan metode KolmogorovSmirnov, menunjukkan nilai signifikansi (Asymp. Sig. (2-tailed)) sebesar 0,352, lebih besar dari 0,05. Artinya asumsi normalitas terpenuhi atau data terdistribusi dengan normal. Hasil uji heteroskedastisitas pada tabel 4 menggunakan metode uji Glejser, menunjukkan nilai kompetensi dosen sebesar 0,629 lebih besar dari 0,05. Hal tersebut mengindikasikan model regresi tidak terdapat heteroskedastisitas. Hasil uji selanjutnya terkait uji koefisien determinasi pada tabel 5, menunjukkan bahwa kompetensi dosen memiliki pengaruh sebesar $0,1 \%$ terhadap prestasi akademik mahasiswa, yang ditunjukkan oleh R Square. Koefisien korelasi yang dinotasikan dengan $\mathrm{R}$ pada penelitian ini memiliki nilai sebesar 0,031. Artinya korelasi atau hubungan antara kompetensi dosen dan prestasi akademik mahasiswa sangat rendah (Neolaka, 2014).

Tabel 2

Analisis regresi linier sederhana

\begin{tabular}{llcc}
\hline \multicolumn{4}{c}{ Coefficients $^{\mathrm{a}}$} \\
\hline Model & B & Sig. \\
\hline 1 & (Constant) & 3,441 &, 000 \\
& $\begin{array}{l}\text { Kompetensi_ } \\
\text { Dosen }\end{array}$ & $-0,001$ &, 570 \\
\hline
\end{tabular}

Tabel 3

Uji normalitas kolmogorov-smirnov

\begin{tabular}{lr}
\hline \multicolumn{2}{l}{ One-Sample Kolmogorov-Smirnov Test } \\
\hline Kolmogorov-Smirnov Z &, 931 \\
Asymp. Sig. (2-tailed) &, 352
\end{tabular}


a. Test distribution is Normal.

b. Calculated from data.

Tabel 4

Uji heteroskedastisitas menggunakan uji glejser

\begin{tabular}{llc}
\multicolumn{3}{c}{ Coefficients $^{\mathrm{a}}$} \\
\hline \multicolumn{2}{c}{ Model } & Sig. \\
\hline \multirow{2}{*}{1} & (Constant) & .000 \\
\cline { 2 - 3 } & Kompetensi_Dosen & .629 \\
\hline
\end{tabular}

a. Dependent Variable: abs_resid

Tabel 5

Uji koefisien determinasi

\begin{tabular}{llll}
\hline \multicolumn{1}{r}{ Model } & $\mathrm{R}$ & $\mathrm{R}$ Square \\
\hline 1 &, 031 &, 001 \\
\hline
\end{tabular}

Kita tentunya tidak dapat mengadakan institusi pendidikan dengan kualifikasi dosen yang buruk. Dosen yang berkompeten masih menjadi aspek penting dan dibutuhkan untuk membantu mahasiswa untuk mendapatkan pengetahuan baik teori maupun praktik secara lebih. Melalui penelitian ini ditemukan bahwa kompetensi dosen adalah hanya salah satu alat dalam meningkatkan prestasi akademik mahasiswa. Terbukti dari hasil hitungan menunjukkan kompetensi dosen hanya berpengaruh sebesar $0,1 \%$ dalam peningkatan prestasi akademik mahasiswa. Memang faktor-faktor lain yang mempengaruhi prestasi akademik mahasiswa bukan hanya melibatkan kompetensi dosen saja. Ada faktor lain yang ikut berperan dalam mempengaruhi prestasi akademik. Beberapa faktor tersebut diantaranya latar belakang keluarga, kondisi ekonomi keluarga, lingkungan pertemanan, dan fasilitas belajar. Apabila faktor-faktor tersebut sudah memuaskan atau sesuai dengan apa yang diharapkan mahasiswa maka akan dapat meningkatkan semangat belajar mahasiswa, yang tentunya akan membantu mahasiswa untuk memberikan dampak positif terhadap pencapaian prestasi akademiknya.
Literatur terdahulu mengenai kompetensi dosen dan prestasi akademik mahasiswa yang dilakukan oleh Abbasi \& Mir (2012) di Gujrat City, Pakistan dengan sampel mahasiswa dari University of Gujrat, ditemukan bahwa pengaruh kompetensi dosen terhadap prestasi akademik mahasiswa menunjukkan hasil signifikan negatif. Sama hal nya dengan yang ditemukan oleh Bonney et al. (2015) yaitu walaupun kualitas guru berada pada kualifikasi tinggi, namun hal itu tidak berdampak pada pencapaian prestasi akademik siswa, atau dengan kata lain memiliki hasil yang negatif. Penelitian tersebut dilakukan di SMP Sekondi Takoradi Metropolitan Assembly di Ghana. Kemudian penelitian oleh Kosgei et al. (2013) di Kenya juga menunjukkan bahwa tidak ada hubungan yang signifikan antara kualifikasi guru dan prestasi akademik siswa.

Begitu pula dengan penelitian yang dilakukan Al-Mutairi (2011) di Kuwait menemukan bahwa tidak ada hubungan signifikan antara kualitas dosen dengan prestasi akademik mahasiswa. Penelitian tersebut memaparkan tingginya kinerja mahasiswa dipengaruhi oleh tiga faktor, yaitu kewarganegaraan mahasiswa, usia mahasiswa, dan nilai akhir yang diraih di SMA oleh mahasiswa. Akan tetapi penelitian lain yang dilakukan di beberapa negara seperti yang dilakukan Sultan \& Shafi (2014), Muzenda (2013), Sang, dkk (2014) menunjukkan bahwa kompetensi guru atau dosen yang tinggi dapat mempengaruhi prestasi akademik mahasiswa secara signifikan positif.

Jadi penelitian yang dilakukan oleh penulis di Indonesia pada industri pendidikan, 
lebih tepatnya pada Fakultas Ekonomi dan Bisnis Telkom University, memperkuat hasil penelitian terdahulu di berbagai negara yang berbeda. Hasilnya menunjukkan bahwa kompetensi dosen tidak memiliki pengaruh terhadap prestasi akademik mahasiswa.

\section{KESIMPULAN}

Berdasarkan pembahasan hasil penelitian yang telah dijelaskan, hipotesis yang diterima pada penelitian ini adalah $\mathrm{H}_{0}$ yaitu, kompetensi dosen tidak memiliki pengaruh yang signifikan positif terhadap prestasi akademik mahasiswa Fakultas Ekonomi dan Bisnis Telkom University tahun angkatan 2014, 2015, dan 2016. Hal tersebut mengindikasikan, pentingnya peran perguruan tinggi dalam memperhatikan kemampuan, pengetahuan, dan kompetensi seorang dosen sehingga kompetensi profesional dosen meningkat, yang kemudian akan mempengaruhi peningkatan performa akademik mahasiswa.

Peran yang dapat dilakukan oleh perguruan tinggi antara lain mengikutsertakan dosen dalam diklat, pelatihan, seminar, atau sertifikasi. Kemudian dosen-dosen diwajibkan untuk mengadakan diskusi dengan sesama dosen yang mengajar mata kuliah yang sama untuk saling berbagi ilmu dan pengalaman dalam proses belajar mengajar. Apabila kompetensi dosen baik atau tinggi, maka akan berdampak pada meningkatnya prestasi akademik mahasiswa.

Penelitian ini memiliki beberapa keterbatasan diantaranya, ruang lingkup penelitian hanya di Fakultas Ekonomi dan Bisnis Telkom University. Metode penelitian hanya menggunakan regresi linier sederhana, dimana hanya melibatkan satu variabel independen yaitu kompetensi dosen dan satu variabel dependen yaitu prestasi akademik mahasiswa. Untuk penelitian di masa mendatang, guna memperbaiki penelitian ini, peneliti selanjutnya dapat menerapkan regresi linier berganda. Sehingga melibatkan variabel independen lain yang dapat mempengaruhi variabel dependen dan hasil temuan penelitian akan memperluas ruang lingkup pembahasan terkait prestasi akademik mahasiswa. Beberapa contoh variabel yang dapat digunakan peneliti selanjutnya adalah kondisi lingkungan sosial, latar belakang keluarga, atau fasilitas belajar.

Tujuan penelitian diharapkan dapat lebih bervariasi tidak hanya terbatas pada pengaruh atau hubungan, tetapi dapat menganalisis permasalahan dan memberikan metode untuk meningkatkan prestasi akademik mahasiswa. Penelitian selanjutnya alangkah lebih baik dilakukan pada perguruan tinggi berbeda, baik perguruan tinggi swasta maupun perguruan tinggi negeri. Sehingga demografi responden lebih beragam. Diharapkan melalui penelitian ini, dapat dijadikan refrensi baik bagi perguruan tinggi atau praktisi akademis.

\section{DAFTAR PUSTAKA}

Abbasi,A. S., \& Mir, G. M. (2012). Impact of Teacher's Ability, Student's Work Ethics and Institutional Environment on Student Performance of University of Gujrat. Middle-East Journal of Scientific Research, 12(4), 572-579. Retrieved from https://papers.ssrn.com/sol3/papers.cfm?abstract_id=2178577

Akiri, A. A., \& Ugborugbo, N. M. (2009). Teachers' Effectiveness and Students' Academic Performance in Public Secondary Schools in Delta State, Nigeria. Studies on Home and Community Science, 3(2), 107-113. https://doi.org/10.1080/09737189.2009.11885284 
Al-Mutairi, A. (2011). Factors Affecting Business Students' Performance in Arab Open University: The Case of Kuwait. International Journal of Business and Management, 6(5), 146-155. https://doi.org/10.5539/ ijbm.v6n5p146

Astuty, E. (2015). Implementation Analysis of Lecturer's Pedagogical Competence on Student's Academic Achievement. Journal of Management Research, 7(2), 152. https://doi.org/10.5296/jmr.v7i2.6834

Aziz, S. (2016). Manajemen Mutu Perguruan Tinggi Koreksi Dan Implementasi. Yogyakarta: Gava Media.

Bonney, E. A., Amoah, D. F., Micah, S. A., \& Lemaire, M. B. (2015). The Relationship between the Quality of Teachers and Pupils Academic Performance in the STMA Junior High Schools of the Western Region of Ghana. Journal of Education and Practice, 6(24), 139-150. Retrieved from https://files.eric.ed.gov/ fulltext/EJ1078818.pdf

Danim, S. (2008). Kinerja Staf Dan Organisasi. Bandung: CV Pustaka Setia.

Ganyaupfu, E. M. (2013). Factors Influencing Academic Achievement in Quantitative Courses among Business Students of Private Higher Education Institutions, 4(15), 57-66. Retrieved from http:// pakacademicsearch.com/pdf-files/edu/413/57-65 Vol 4, No 15 (2013).pdf

Kosgei, A., Mise, J. K., Odera, O., \& Ayugi, M. E. (2013). Influence of teacher characteristics on students' academic achievement among secondary schools. Journal of Education and Practice , 4(3), 76-82. Retrieved from https://eprints.usq.edu.au/23286/1/Kosgei.pdf

Mediawati, E. (2010). Pengaruh Motivasi Belajar Mahasiswa Dan Kompetensi Dosen Terhadap Prestasi Belajar. Dinamika Pendidikan, 5(2). https://doi.org/10.15294/DP.V5I2.4922

Moeheriono. (2010). Pengukuran kinerja berbasis kompetensi (competency based human resource management). Bogor: Ghalia Indonesia.

Mushtaq, I., Khan, S. N., Shabana, It., \& Khan, N. (2012). Factors Affecting Students’ Academic Performance. Global Journal of Management and Business Research Type: Double Blind Peer Reviewed International Research Journal Publisher, 12(1). Retrieved from https://globaljournals.org/GJMBR_Volume12/3Factors-Affecting-Students-Academic.pdf

Mustofa, B. (2015). Psikologi Pendidikan: Pendekatan, Orientasi, dan Perspektif Baru Sebagai Landasan Pengembangan Strategi dan Proses Pembelajaran (Teori dan Praktik). Yogyakarta: Parama Ilmu.

Muzenda, A. (2013). Lecturers' Competences and Students' Academic Performance. International Journal of Humanities and Social Science Invention ISSN (Online, 2319-7722.

Neolaka, A. (2014). Metode Penelitian Dan Statistik Untuk Perkuliahan, Penelitian Mahasiswa Sarjana Dan Pascasarjana. Jakarta: Rosda.

Rahmawati, R., Siswandari; \& Ivada, E. (2013). Faktor-Faktor Yang Memengaruhi Prestasi Belajar Siswa Boarding School Man 1 Surakarta.Jupe-Jurnal Pendidikan Ekonomi, 1(2). Retrieved from http://jurnal.fkip.uns. ac.id/index.php/ekonomi/article/view/2379

Sang L. C., Ibrahim, Z., \& Owee Kowang, T. (2014). An Analysis on the Relationship between Lecturers' Competencies and Students' Satisfaction. International Education Studies, 7(1), 297-300. https://doi. org/10.5539/ies.v7n1p37

Silalahi, U. (2015). Metode Penelitian Sosial Kuantitatif (Edisi Revisi). Bandung: Refika Aditama.

Simamora, B. (2014). Pengaruh Disiplin Dan Kompetensi Dosen Terhadap Prestasi Mahasiswa Program Studi Penerbitan. Jurnal Publipreneur, 2(4), 98-113.

Sujarweni, V. W. (2016). Kupas Tuntas Penelitian Akuntansi Dengan SPSS. Yogyakarta: Pustaka Baru Press.

Sultan, S., \& Shafi, M. (2014). Impact of Perceived Teachers' Competence on Students' Performance: Evidence for Mediating/ Moderating Role of Class Environment. Journal on Educational Psychology, 8(1), 10-18. Retrieved from https://eric.ed.gov/?id=EJ1098630

Wagiran. (2013). Kinerja Guru (Teori, Penilaian dan Upaya Peningkatannya). Yogyakarta: Deepublish.

Wamala, R., \& Seruwagi, G. (2012). Teacher Competence And The Academic Achievement Of Sixth Grade Students In Uganda. Journal of International Education Research (JIER), 9(1), 83-90. https://doi. org/10.19030/jier.v9i1.7503 